\title{
CONSENSUAL JUSTICE IN CROATIAN CRIMINAL PROCEDURAL LAW: THE NEED FOR A SYSTEMATIC APPROACH*
}

\author{
Elizabeta Ivičević Karas, PhD, Full Professor \\ University of Zagreb, Faculty of Law \\ Trg Republike Hrvatske 14, 10000 Zagreb \\ elizabeta.ivicevic@pravo.hr
}

\begin{abstract}
Croatian criminal procedure has undergone a number of reforms over the last twenty years, which have primarily been conditioned by harmonisation with European legal standards, but also by an effort to make criminal proceedings as efficient and economical as possible. Different forms of consensual procedures, even if they deviate from some fundamental principles of criminal procedure, may be appropriate tools for achieving faster and more efficient criminal proceedings, provided they are adequately regulated and applied. They also contribute to the humanisation of criminal justice, especially in the prosecution of less serious criminal offences. The paper analyses legislative developments and domestic research that have been conducted so far, which show that the Croatian legislator, following tendencies in comparative law, has gradually expanded the scope of the application of different consensual forms without adopting, at any time, a criminal policy platform for their introduction into Croatian criminal procedure. In addition, the legislator has not always been consistent when addressing various aspects of particular forms of consensual procedures, such as the gravity of criminal offences in relation to which a particular form of agreement is possible, the role of the court, and especially the power of the court to review the agreement of the parties, victims rights and the procedural role of victims, as well as procedural and defence rights. A particular problem is that there are no clear distinctions, either at the legislative level or in practice, between the specific objectives of certain forms of agreements of the parties. Therefore, this research focuses on the problem of imprecision and inconsistency in the regulation of the fundamental aspects of various forms of consensual procedures, which harms the transparency of the criminal justice system. Finally, besides detecting and critically analysing the above-mentioned deficiencies, the paper offers possible guidelines on how to adopt a systematic approach in regulating different forms of consensual procedures at the normative level and in practice, and thereby provide more consistent and transparent use of consensual justice in Croatian criminal procedure.
\end{abstract}

Keywords: consensual justice, negotiated justice, consensual procedure, criminal procedure

This work has been fully supported by the Croatian Science Foundation under the project "Systematic approach to models of negotiated justice in Croatian criminal procedure" (IP-2019-04-1275) 


\section{INTRODUCTION}

The criminal justice systems of many continental European countries, including the Croatian one, have been minutely built on fundamental principles such as the principle of legality (or mandatory prosecution), the principle of ex officio prosecution, and the inquisitorial principle which implies the establishment of substantive truth. These principles are the mainstay of the inquisitorial model of criminal proceedings, while the cornerstone of modern national procedures is the principle of a fair trial, ${ }^{1}$ proclaimed in international and European human rights documents and elaborated during the last few decades in the jurisprudence of the European Court of Human Rights. In complying with all the procedural principles, contemporary criminal procedure is becoming increasingly demanding, complicated and expensive, while at the same time domestic legal systems search for more economical, efficient and expedient criminal justice. Hence, modern legal systems face the challenge of balancing between the two tendencies by embracing consensual, negotiated or "bargained" justice.

Introducing consensual justice into national legal systems has raised countless academic debates, for the very concept "seems to collide with the very structure of criminal procedure" ${ }^{3}$ Transparent, modern criminal procedure, founded on the concept of a fair trial, still entails holding a fair, public hearing as its central stage, while different consensual forms generally exclude it, just as each one of them, to certain extent, deviates from other fundamental procedural principles. As Damaška pointed out, "avoiding public hearings reduces the transparency of the judiciary and makes it more difficult to control judicial activity". ${ }^{4}$ In this sense, introducing consensual justice implies not only technical change in the process, but also a change of how the criminal justice system is perceived by the defendants, victims and the public in general. ${ }^{5}$ At the same time, the ideas of restorative justice, resocialisation and humanisation of criminal law change the paradigm that criminal proceedings should serve exclusively "as an instrument of the functional-

Krapac, D., Kazneno procesno pravo, Prva knjiga: Institucije, Narodne novine, Zagreb, 2015, p. 150-156 All these terms are used in literature and they refer to various models of consensual procedures, based on the consent of both parties to criminal proceedings. See Ivičević Karas, E.; Puljić, D., Presuda na temelju sporazuma stranaka u hrvatskom kaznenom procesnom pravu i praksi Županijskog suda u Zagrebu, Hrvatski ljetopis za kazneno pravo i praksu, vol. 20, no. 2, 2013, p. 824

3 Jung, H., Plea Bargaining and its Repercussions on the Theory of Criminal Procedure, European Journal of Crime, Criminal Law and Criminal Justice, vol. 5, no. 2, 1997, p. 116

4 Damaška, M., Napomene o sporazumima u kaznenom postupku, Hrvatski ljetopis za kazneno pravo i praksu, vol. 11, no. 1, 2004, p. 18

5 With regard to plea-bargaining, see Alkon, C., Plea Bargaining as a Legal Transplant: A Good Idea for Troubled Criminal Justice Systems, Transnational Law \& Contemporary Problems, vol. 19, 2010, pp. 356-357 
ity of public punishment of offenders", ${ }^{6}$ especially with regard to less serious criminal offences. Therefore, introducing and expanding the scope of application of different consensual forms in any legal system requires taking a careful, balanced and systematic approach to the issue.

Croatian criminal procedure has undergone a number of reforms over the last twenty years, which have primarily been conditioned by harmonisation with European legal standards, but also by the effort to make criminal proceedings as efficient and economical as possible. The trend of speeding up criminal procedure through the introduction of various forms of consensual procedures has been present in the comparative law of European countries of the continental legal tradition for the past few decades, ${ }^{7}$ and the Croatian legislator started to follow the trend in the late 1990s. Most consensual procedures adopted by the Croatian legislator have been modelled on consensual forms developed in the systems of the Anglo-American legal tradition, or, more precisely, on variants of these forms adopted by European continental states. Since then, the possibility to use different consensual procedural forms in Croatian law has been gradually but significantly expanding. ${ }^{8}$ One of the main goals of adopting the new Criminal Procedure Act in 2008 was speeding up the criminal procedure, inter alia, through the wider possibilities of using different consensual instruments. ${ }^{9}$

Meanwhile, several studies have been conducted on various forms of consensual procedures in Croatian law. Yet there has been no comprehensive and thorough study based on the systematic approach to the issue of consensual justice, and no satisfactory study that offers an analysis of the effects of expanding different consensual forms on the domestic criminal justice system as a whole. In the United States, whose consensual forms serve as role models to European legal systems, up to as many as ninety-five percent of all convictions are based on guilty pleas, ${ }^{10,11}$

${ }^{6} \quad$ Krapac, D., Presuda na zahtjev stranaka u stadiju istrage u hrvatskom kaznenom postupku, in: Pavišić, B. (ed.), Decennium Moztanicense Rijeka, 2008, p. 138

7 Jimeno-Bulnes, M., American Criminal Procedure in a European Context, Cardozo Journal of International \& Comparative Law, vol. 21, 2013, p. 452-453

8 See Ivičević Karas, E., Trial Waiver Systems in Croatia, Towards a Rights-based Approach to Trial Waiver Systems, LEAP, 2019, p. 12-13, accessible at: [https://www.fairtrials.org/sites/default/files/publication pdf/20190513_Trial_Waivers_Croatia_Final.pdf], accessed 20. April 2020

9 Pavišić, B., Novi hrvatski Zakon o kaznenom postupku, Hrvatski ljetopis za kazneno pravo i praksu, vol. 15, no. 2, 2008, p. 517

10 Vitiello, M., Bargained-for-Justice: Lessons from the Italians, The University of the Pacific Law Review, vol. 48, 2017, p. 255

11 A conviction based on a guilty plea does not necessarily imply formal plea-bargaining. Garoupa, N.; Stephen, F. H., Why Plea-Bargaining Fails to Achieve Results in So Many Criminal Justice Systems: A New Framework for Assessment, Maastricht J. Eur. \& Comp. L., vol. 15, no. 3, 2008, p. 324 
while at least ninety percent of all criminal cases are resolved through plea-bargaining. ${ }^{12}$ In Croatia, these percentages are still significantly lower. ${ }^{13}$ The question now raised is whether the Croatian legal system should attempt to reach similar percentages to the American ones, by continuously expanding the possibilities of resolving criminal cases through different forms of consensual justice, or should the conduct of criminal proceedings, including public trials, still be the principal response to alleged criminal offences? The answer to this complex question is primarily a matter of criminal policy, which should provide a corresponding platform prior to any legislative initiative or reform in the area of consensual justice. This paper has no pretensions to try to offer such a platform; instead, in reference to the current state, it attempts to demonstrate whether the existing consensual forms in Croatian criminal procedure are coherent and clear and whether they provide transparency in proceedings, having in mind that transparency in proceedings and decision-making is still one of the basic conditions for achieving the purpose of modern criminal procedure. ${ }^{14}$ This will not be done through a detailed study of each form of consensual procedure existing in Croatian law, but, instead, through a study of key issues that may be detected as problematic from an analysis of the normative framework and from the results of different studies conducted so far. These issues include the following elements: specific objectives of each form of consensual procedure, the gravity of criminal offences in relation to which a particular form of agreement is possible, the role of the court and especially the power of the court to review the agreement of the parties, victims' rights and the procedural role of victims, and, finally, procedural and defence rights. This paper argues that regulating (at a normative level and in practice) negotiated justice requires a systematic approach, which implies that all forms of consensual procedures should be mutually coherent in respect of the relevant elements, as well as transparent in application.

12 Alkon, op. cit. note 5, p. 393

13 The latest statistics show that in 2019, 4.03\% of all judgments of conviction were based on the agreement of the parties. Izvješće Državnog odvjetništva Republike Hrvatske o radu državnih odvjetništava u 2019. godini, Državno odvjetništvo Republike Hrvatske, Zagreb, travanj 2020., p. 43, available at: [http://www.dorh.hr/dorh05052020], accessed 03. May 2020

14 As Krapac defines it, the purpose of modern criminal proceedings is to "ensure the application of state instruments of public punishment through standardised rules for deciding on the existence of a criminal offence and the guilt of the perpetrator". Krapac, op. cit. note 1, p. 22 


\section{INTRODUCING CONSENSUAL JUSTICE IN CROATIAN CRIMINAL PROCEDURE: A BRIEF OVERVIEW OF DIFFERENT CONSENSUAL FORMS}

The history of consensual justice in Croatian criminal procedure dates back to the relatively recent year of 1998, when the Criminal Procedure Act enacted in 1997 (CPA/97) ${ }^{15}$ came into force. The CPA/97 was the first criminal procedure codification of the Republic of Croatia after its independence, where one of the legislative goals was to "unburden the criminal justice system and introduce such procedural forms that will, on the basis of strengthening party autonomy, open up opportunities for the faster and more efficient resolution of criminal cases". ${ }^{16}$ The CPA/97, the original text and the legislative amendment of 2002, introduced five types of consensual procedures: the penal order, conditional deferral or withdrawal of criminal prosecution (so-called "diversion"), judgment at the request of the parties in the investigation, judgment in the case of a guilty plea at the trial (for less serious criminal offences) and a particular consensual form that could be considered as a precursor to the crown witness (see infra 2.3). The scope of application of these consensual forms gradually expanded, either through the amendments of the CPA/97, or in special legislation, or in the new Criminal Procedure Act of $2008^{17}$ (hereinafter: CPA) which introduced another consensual form - witness immunity. Besides legislation, consensual forms are regulated in numerous instructions of the State Attorney General, which refer to different forms of consensual procedures, ${ }^{18}$ and particularly in the Instructions of the State Attorney General on proceedings during bargaining with the suspect/defendant on terms of pleading guilty and the punishment ${ }^{19}$ (hereinafter: Instructions). These Instructions are an internal document binding on all state attorneys and their deputies, and they regulate negotiating and agreeing with the defendant on a guilty plea and on sanctions in the case of a judgment based on the agreement of the parties, but also in the case of consensual forms applied for less serious criminal offences.

Some consensual procedures, regulated in the legislation in force, are based on the principle of legality (or mandatory prosecution) which still strongly dominates

\footnotetext{
15 Zakon o kaznenom postupku, Official Gazette 110/97, 27/98, 58/99, 112/99, 58/02, 143/02, 115/06

16 Krapac, D., Zakon o kaznenom postupku i drugi izvori hrvatskog kaznenog postupovnog prava, Narodne novine, Zagreb, 2008, p. 10

17 Zakon o kaznenom postupku, Official Gazette 152/08, 76/09, 80/11, 121/11, 91/12, 143/12, 56/13, $145 / 13,152 / 14,70 / 17,126 / 19,126 / 19$

18 See in Sirotić, V., Uvjetna odgoda kaznenog progona punoljetnog počinitelja kaznenog djela, Hrvatski ljetopis za kazneno pravo i praksu, vol. 19, no. 1, 2012, p. 166

19 Naputak o pregovaranju i sporazumijevanju s okrivljenikom o priznanju krivnje i sankciji, O-2/09, od 17. veljače 2010., accessible at: [http://www.dorh.hr/PresudaPoSporazumu], accessed 27. April 2020
} 
in Croatian criminal procedural law and these consensual forms actually imply the conviction of the defendant who has expressly or tacitly agreed with the state attorney's charge and the proposed sanction. Other consensual forms are based on the principle of discretionary prosecution which allows the state attorney to give priority to some specific objectives over the conduct of criminal proceedings and reaching a conviction, but strictly under the conditions explicitly prescribed by law. ${ }^{20}$ Furthermore, some consensual forms operate on the principle of an offer by the state attorney, which the defendant may accept or reject, while other forms include negotiation or bargaining between the parties. ${ }^{21}$ Finally, some consensual forms are matched when it comes to the category of the criminal offences to which they may apply (i.e. only to less serious criminal offences, or only to serious criminal offences), or the specific purposes of negotiated justice (humanisation of criminal proceedings, economy, the acceleration of criminal proceedings, and obtaining evidence of another criminal offence and/or of another perpetrator), which will be analysed in detail infra.

\subsection{Consensual procedures for less serious criminal offences: judgment in the case of a guilty plea at the trial, the penal order and "diversion"}

The CPA/97 initially introduced two types of consensual forms into Croatian criminal procedure - the penal order and the conditional deferral or withdrawal of criminal prosecution ("diversion"). ${ }^{22,23}$ Both instruments were initially intended to be applied in proceedings for less serious criminal offences, punishable by a fine or imprisonment of up to three years. The penal order implied sentencing, without holding a trial, to less grave punishments excluding the unconditional prison sentence (Article $446 \mathrm{CPA} / 97)$. On the other hand, the conditional deferral or withdrawal of criminal prosecution ${ }^{24}$ was based on the state attorney's decision not to prosecute, in the case of a lower degree of guilt and if the scale of the harmful consequences actually did not require criminal prosecution in the public inter-

\footnotetext{
20 See in more detail Ivičević Karas, op. cit. note 8, p. 6-7

21 See Damaška, op. cit. note 4, p. 4

22 Diversion designates an "out of court settlement" as an alternative to formal criminal proceedings. Puharić, B.; Radić, I., Primjena načela svrhovitosti u postupanju prema maloljetnicima, Hrvatski ljetopis za kazneno pravo i praksu, vol. 22, no. 2, 2015, p. 637

23 The term "diversion" has not yet become quite common in the Croatian legal lexicon, but it is used in the literature (see ibid., and Sirotić, op. cit. note 18, p. 164-165)

24 Conditional deferral and conditional withdrawal of criminal prosecution are basically the same instrument -conditional deferral is applied before the initiation of criminal proceedings while conditional withdrawal is applied after the commencement of criminal proceedings. See Glasnović Gjoni, V.; Sirotić, V., Uvjetni odustanak od kaznenog progona i praksa Općinskog suda u Puli-Pola, Pravni vjesnik, vol. 32, no. 3-4, 2016, p. 159
} 
est. In return, the defendant had to assume and fulfil certain obligations (Article 175 CPA/97), usually qualified as "informal sanctions". ${ }^{25}$ This meant that the state attorney was actually granted the right to sanction "criminal wrongdoing" at the earliest stages of the procedure and out of court. ${ }^{26}$ The instrument was first developed in juvenile criminal law ${ }^{27}$ and was then transposed to regular criminal procedure with the intention of speeding up the pre-trial stage and enabling state attorneys to focus on more serious criminal offences. ${ }^{28}$

In the legislative amendment to the CPA/97 in 2002, the scope of application of the penal order was extended to criminal offences punishable by a fine or imprisonment of up to five years, and the same extension was provided for the conditional deferral or withdrawal of criminal prosecution in the new CPA of 2008. In addition, the new CPA extended the possibility to apply this instrument by omitting the requirements of a lower degree of guilt, or a smaller scale of harmful consequences of the criminal offence. Imprisonment of up to five years is still an upper limit for the application of both consensual forms, and their fundamental characteristics remained as described above.

Besides conditional deferral or the withdrawal of criminal prosecution and the penal order, the CPA/97 regulated a specific form of tacit agreement, introduced with the legislative amendment of 2002, applicable for criminal offences punishable by a fine or imprisonment of up to five years. In the indictment, the state attorney would propose a certain type and measure of punishment to the court, and if the accused pleaded guilty and agreed with the proposal, the court could not impose another type or greater measure of punishment than the proposed one (Article $442(4,5) \mathrm{CPA} / 97)$. The same consensual instrument is regulated in the new CPA of 2008 (Article 417.a(6,7) CPA).

According to the legislation in force, all three described consensual forms refer to the same group of offences. While the penal order and judgment in the case of a

25 These obligations (or "informal sanctions") included the obligation to repair or compensate the damage caused by a criminal offence, the obligation to pay a certain amount in favour of a public institution, for humanitarian or charitable purposes, or to a fund for compensation to victims of criminal offences, to pay alimony due, to carry out community service work while at liberty, to undergo treatment for particular addiction or psychosocial therapy in order to eliminate violent behaviour with the consent of the suspect to leave the family community during the therapy. Compare with the regulation in force in Ivičević Karas, op. cit. note 8, p. 6

26 Krapac, op. cit. note 16, p. 38

27 Carić, M., Načelo surhovitosti (oportuniteta) kaznenog progona iz članka 175. Zakona o kaznenom postupku i njegova primjena u praksi, Hrvatski ljetopis za kazneno pravo i praksu, vol. 8, no. 1, 2001, pp. 612-614

28 Ibid., p. 604 
confession at the trial are regulated in compliance with the principle of legality (or mandatory prosecution), the conditional deferral or withdrawal of criminal prosecution is based on the principle of discretionary prosecution. On one hand, issuing a penal order implies a conviction without holding a trial if, first, the court agrees with the state attorney's request for the issuance of a penal order (Article 541(1) CPA), and then the defendant tacitly agrees to this by not lodging an objection (Article $542 \mathrm{CPA}$ ). Lodging an objection against the penal order would result in holding a trial. The judgment in the case of a confession at the trial implies that the defendant explicitly agrees with the proposed punishment once the trial has started, which will result in a conviction. Judicial control is exercised in favour of the defendant, in the sense that the court may always pronounce a more lenient punishment than the agreed one, and, in order to be able to do so, the court is obligated to continue the hearing and to present evidence that is relevant to the decision on the punishment or other measure (Article 417.a(4) CPA).

On the other hand, the conditional deferral or withdrawal of criminal prosecution is, as already mentioned, based on the principle of discretionary prosecution, meaning that the execution of an informal sanction agreed between the defendant and the state attorney precludes further criminal proceedings and the conviction (Article 206.d CPA). The court is in no way involved in this consensual procedure, so there is no judicial control over the discretionary decision of the state attorney. Yet, the state attorney must obtain the consent of the victim or the injured party (Article 206.d(1) CPA), which is not required for the penal order.

The purpose of all three described instruments is economy and the acceleration of proceedings. The specific purpose of a penal order and the conditional deferral or withdrawal of criminal prosecution is also the humanisation of proceedings by sparing the defendant from the burden of a public trial and, as regards conditional deferral or withdrawal, also from all the consequences of conducting formal criminal proceedings. Therefore, the position of the defendant, who agrees to one of these two consensual forms, is significantly different, which will be discussed in more detail infra (3).

\subsection{The Croatian model of plea-bargaining: Judgment based on the agreement of the parties}

Judgment based on the agreement of the parties, based on the Anglo-American model of plea-bargaining, but also on its European versions - the Italian pattegiamento, the Spanish conformidad, or the German Absprachen im Strafprozess ${ }^{29}$ - was

$29 \quad$ Krapac, op. cit. note 16, p. 39 
first introduced into Croatian criminal procedure, in the form of a judgment at the request of the parties in the investigation, in the legislative amendment to the $\mathrm{CPA} / 97$ in $2002 .{ }^{30}$ It could be applied for criminal offences punishable by imprisonment of up to ten years, and for more than five years. More serious criminal offences were excluded from bargaining, as were less serious criminal offences, since there were other forms of consensual procedures which were considered more suitable (supra 2.1). ${ }^{31}$ The basic feature of judgment at the request of the parties in the investigation, in which it differed significantly from the American model, was that the parties were not permitted to agree on the legal qualification of the criminal offence, but only on the type and measure of the punishment. This feature has been retained in the regulation of judgment based on the agreement of the parties, an instrument which replaced judgment at the request of the parties in the new CPA/08.

The main difference between the two instruments is that the latter may be applied to all criminal offences, notwithstanding their gravity. Therewith, the new law has greatly expanded the scope of this consensual form. The grounds for such expansion cannot be found in the reasoning given with the Proposal of the new $\mathrm{CPA} / 08,32$ but it can be assumed that the legislator was motivated by efforts to strengthen the efficiency of criminal proceedings. Yet, in practice, judgment based on the agreement of the parties is often used as an instrument to obtain from the defendant data and evidence on other criminal offences and other perpetrators, as well as to secure testimony that the defendant will give in the capacity of witness in other criminal proceedings, against another perpetrator, and for another criminal offence, which will be discussed in more detail infra (3.1).

Judgment based on the agreement of the parties implies that the statement of the parties (on the agreement) is submitted to a court, which may refuse it if it is not in accordance with the sentencing prescribed by law, or if the agreement is not otherwise lawful (see infra 3.3) (Article 361(3) CPA). If the court accepts the statement, it is bound by the type and measure of the punishment specified in the submitted statement (Article $361 \mathrm{CPA}$ ).

The state attorney must obtain the consent of the victim only in cases of criminal offences against life and limb and criminal offences against sexual liberty, which

\footnotetext{
30 Zakon o izmjenama i dopunama Zakona o kaznenom postupku, Official Gazette 58/02

31 Mrčela, M., Presuda na zahtjev stranaka u istrazi, Hrvatski ljetopis za kazneno pravo i praksu, vol. 9 , no. 2, 2002, p. 361. Also Krapac, op. cit. note 16, p. 373

32 Nacrt konačnog prijedloga Zakona o kaznenom postupku, p. 188, accessible at: [https://vlada.gov.hr/ UserDocsImages//2016/Sjednice/Arhiva//57_13.pdf], accessed 24. April 2020
} 
are punishable by imprisonment of more than five years (Article 360(1) CPA). If the direct victim died, consent should be given by close relatives.

\subsection{Consensual procedures for the purpose of obtaining witness statements: The crown witness, abolishment or reduction of sentences and witness immunity}

The crown witness and witness immunity, although regulated under rather different legal regimes, will be considered together, since the main purpose of both consensual forms is to obtain testimony that can be used to reveal and prove other criminal offences and perpetrators. The CPA/97 stipulated that the State Attorney General could decide not to prosecute a member of a criminal organisation/association for the purpose of discovering other offences and members of a criminal organisation/association, provided that it was proportionate to the gravity of the committed offences and the importance of the statement (Article 176 CPA/97). This instrument was then regulated in more detail in the new lex specialis enacted in 2001 - the Act on the Office for the Suppression of Corruption and Organised Crime (hereinafter: Act on USKOK), ${ }^{33}$ which was replaced by a new Act in 2009. ${ }^{34}$ According to the legislation in force, the procedure of granting the status of crown witness implies the application of a particular proportionality test. Thus, a member of a criminal organisation may only be granted the status of crown witness if there are circumstances allowing the mitigation or remission of punishment (Article 36(1)1 of the Act on USKOK). In addition, the statement must be proportionate to the gravity of the committed offence, as well as to its significance for revealing, proving and preventing other criminal offences of the criminal organisation/association (Article 36(1)2 of the Act on USKOK). ${ }^{35}$ The status is granted by the court panel of the county court composed of three judges, at the request of the State Attorney General.

Another form of consensual procedure (Article 37 of the Act on USKOK), which resembles that of the crown witness, provides the possibility of abolishing or reducing the sentence, or releasing on parole a convicted member of a criminal organisation/association, in exchange for testimony. The testimony must be relevant for disclosing and proving other criminal offences committed within a criminal organisation/association, or perpetrators, or for preventing such criminal offences. The court decides at the request of the State Attorney General.

\footnotetext{
33 Zakon o Uredu za suzbijanje korupcije i organiziranog kriminaliteta, Offical Gazette 88/01, 12/02, 33/05, 48/05, 76/07

34 Zakon o Uredu za suzbijanje korupcije i organiziranog kriminaliteta, Offical Gazette 76/09, 116/10, 145/10, 57/11, 136/12, 148/13, 70/17

35 Ivičević Karas, op. cit. note 8, p. 7
} 
Finally, witness immunity was the last introduced consensual form in the new CPA/08. The state attorney may apply this instrument in a situation where a witness refuses to answer a particular question to avoid exposing himself/herself or a close relative to criminal prosecution, severe shame or significant material damage, while the answer to that particular question is important for proving another person's serious offence which is listed in the legal catalogue (Article 286(2) CPA). The instrument, similar to that of the crown witness, implies a particular proportionality test, ${ }^{36}$ contained in the requirement that the criminal offence, for which the witness could be charged, must not be punishable by imprisonment of ten years or more, and in any case it must be punishable by a more lenient punishment than that of the criminal offence which is the object of the testimony and which must be, as mentioned, listed in the legislative catalogue (Article 286(4) $\mathrm{CPA}$ ). The decision to grant the witness immunity is left to the discretion of the state attorney while the court is not involved in the procedure.

Comparing witness immunity to the crown witness, it can be noted that the two instruments coincide for a specific purpose - proving other, more serious criminal offences, especially organised crime and corruption, and revealing and prosecuting the perpetrators of such offences. They also coincide for the requested proportionality, as was previously explained. On the other hand, there are substantial differences between them. First, the status of crown witness is granted to a suspect or defendant, while witness immunity is granted to a witness, i.e. a person who is not (yet) under suspicion of having committed a criminal offence and whose answer to a particular question could (potentially) raise that suspicion. Secondly, granting witness immunity is completely entrusted to the state attorney, while granting the status of crown witness is under the jurisdiction of the court.

Finally, these two instruments can be compared with judgment based on the agreement of the parties, which may also have for its purpose the proving of other criminal offences and revealing and prosecuting the perpetrators of such offences, including corruption and organised crime. According to some research and the latest statistical data, judgment based on the agreement of the parties is used in approximately fifty percent of cases for criminal offences under the jurisdiction of the Office for the Suppression of Corruption and Organised Crime. ${ }^{37}$ Research conducted at Zagreb County Court also showed that judgment based on the agreement of the parties is the main "tool" for finishing the criminal proceedings

\footnotetext{
36 This test was introduced after the intervention of the Constitutional Court in 2012 (U-I-448/2009, points 143-146.3, Official Gazette 91/12). See ibid., p. 7

$37 \quad$ Ibid., p. 4
} 
in cases of organised crime and corruption. ${ }^{38}$ This means that this instrument is a serious "competitor" to that of the crown witness which is designed as an instrument of consensual justice serving precisely the purpose of revealing and proving the most serious criminal offences, including corruption and organised crime, and particularly terrorism, ${ }^{39}$ but it is rarely used in practice. ${ }^{40}$ The problem, and the main distinction, is that judgment based on the agreement of the parties wholly neglects the requirements of proportionality and implies only limited judicial control, a problem which will be discussed infra.

\section{SOME KEY ISSUES}

\subsection{The objectives of consensual procedures}

Introducing consensual procedures into national legal systems, as explained in the Introduction, is most often justified by the need to increase the efficiency of proceedings and the need to reduce their costs, but also with attempts to humanise criminal prosecution. All of these purposes are commonly inherent in the consensual procedures that national legal systems envisage for less serious criminal offences: the penal order and the conditional deferral or withdrawal of criminal prosecution. Yet, even if both these consensual forms are envisaged for the same group of criminal offences, for basically the same purpose, the legal regime of their application is rather different, as is the legal position of the defendant. In a particular case, which of the two consensual forms should be applied depends on the discretion of the state attorney. The State Attorney General's Instructions do not offer more concrete guidelines on the issue. Research conducted so far has shown that this may result in rather inconsistent state attorney practice. For instance, there may be great discrepancy in the application of conditional deferral or withdrawal of criminal prosecution between different county state attorney offices, despite the existing internal instructions ${ }^{41}$ Besides, there is a great disproportion in the application of this instrument and the penal order. On one hand, according to the available statistics, the conditional deferral or withdrawal of criminal prosecution has very rarely been applied in practice: it was applied in $1.48 \%$ of

38 Turudić, I.; Pavelin Borzić, T.; Bujas, I., Sporazum stranaka u kaznenom postupku - trgovina pravdom ili?, Pravni vjesnik, vol. 32, no. 1, 2016, p. 123, 148

39 See Labs, K., Die Strafrechtliche Kronzeugenregelung - Legitimation einer rechtlichen Grauzone? Tectum Verlag, Marburg, 2016, p. 28-29

40 There are no publically available data on the use of crown witness in practice. See Ivičević Karas, op. cit. note 8, p. 7

${ }^{41}$ Sirotić, $o p$. cit. note 18 , p. 170 
all dismissed crime reports against adults in $2015,{ }^{42} 1.2 \%$ in $2016,{ }^{43}$ and $1.7 \%$ in $2017 .{ }^{44,45}$ On the other hand, the statistics show that from 2014 to 2017 the penal order was requested in nearly $40 \%$ of all indictments. ${ }^{46}$ The dominant application of the penal order may be explained by its "less complicated" procedure, ${ }^{47}$ even in cases where a conditional deferral or withdrawal of criminal prosecution could actually be a more appropriate instrument. The problem is that it requires the state attorney first to reach an agreement, and then to check whether the defendant has fulfilled the assumed obligations, which can last up to a year and requires the constant and significant engagement of the state attorney. Yet, such a large margin of discretion left to state attorneys puts defendants in an unequal position, it does not contribute to the transparency of consensual justice, and requires further and more detailed regulation at the normative level and in practice.

The particular purpose of bargaining - obtaining testimony, i.e. evidence on other criminal offences and/or other perpetrators - complements efforts to increase the efficiency of criminal proceedings: the efficiency of proceedings concluded with the use of a certain consensual form, and/or the efficiency of other criminal proceedings that will "benefit" from the testimony obtained from the "former" defendant, now questioned as a witness. Yet, this specific purpose of consensual justice is related to the problem of mixing procedural roles. In Croatian criminal procedure, as in most legal orders of the continental legal tradition, in the same criminal proceedings one person cannot be both a defendant and a witness. ${ }^{48}$

42 Izvješće Državnog odvjetništva Republike Hrvatske za 2015. godinu, A-447/15, Državno odvjetništvo Republike Hrvatske, Zagreb, travanj 2016., p. 43-44, available at: [http://www.dorh.hr/IzvjesceDrzavnogOdvjetnistvaRepublikeHrvatske], accessed 29. April 2020

43 Izvješće Državnog odvjetništva Republike Hrvatske za 2016. godinu, A-561/16, Državno odvjetništvo Republike Hrvatske, Zagreb, travanj 2017., p. 37, available at: [http://www.dorh.hr/IzvjesceDrzavnogOdvjetnistvaRepublikeHrvatskeZa], accessed 29. April 2020

44 Izvješće Državnog odvjetništva Republike Hrvatske za 2017. godinu, A-643/17, Državno odvjetništvo Republike Hrvatske, Zagreb, travanj 2018., p. 37, available at: [http://www.dorh.hr/dorh07062018], accessed 29. April 2020

45 It should be stressed that the Reports for 2016 and 2017 state that in these cases, as a rule, "conditional opportunity" (i.e. "diversion") was applied, which means that cases of "unconditional opportunity" may also be included in this percentage. Ibid.

46 See Ivičević Karas, op. cit. note 8, p. 5. The most recent available statistical data refer to 2017 and show that the penal order was requested in $37.05 \%$ of all indictments against adult perpetrators. Statistički ljetopis 2018, p. 558, available at: [https://www.dzs.hr/Hrv_Eng/ljetopis/2018/sljh2018.pdf], accessed 07. May 2020. For the earlier period, see Bonačić, M., Kritički osvrt na hrvatsko zakonodavno uredenje instituta kaznenog naloga, Hrvatski ljetopis za kazneno pravo i praksu, vol. 22, no. 1, 2015, p. 188

47 Sirotić, op. cit. note 18, p. 206

48 Ivičević Karas, E., Prilog raspravi o problemu miješanja procesnih uloga u kaznenom postupku, in: Turković, K.; Munivrana Vajda, M.; Dragičević Prtenjača, M. (eds.), Kazneno pravo: sinergija teorije i 
This is because the defendant and the witness have different procedural functions, and therefore different procedural rights and duties: the defendant has the right to refuse to give a statement, but, if he/she does, he/she cannot be held liable for giving an untrue statement, unlike a witness who is obliged to testify truthfully, under the threat of criminal liability for giving false testimony. ${ }^{49,50}$ Regulation of the matter is quite different in the legal orders of the Anglo-American legal tradition, where the defendant can decide whether to testify, but if he/she testifies, he/ she is examined as a witness and is obliged to testify truthfully, under the threat of criminal liability for perjury. ${ }^{51}$ This distinction is of particular relevance, knowing that consensual forms that serve this particular purpose, such as that of the crown witness, originated in Anglo-American legal systems. ${ }^{52}$

Two instruments that are clearly envisaged for this purpose in Croatian criminal procedure are the crown witness and witness immunity. As already explained, both of these instruments are applicable to facilitate prosecuting and proving more serious criminal offences, but they are excluded in respect of defendants who are or could be charged with the most serious criminal offences. On the other hand, judgment based on the agreement of the parties is the only consensual form based on the principle of legality applicable to the most serious criminal offences, with the possibility of the significant reduction of the bargained punishment. Yet, the problem of mixing procedural roles is particularly emphasised in the context of rendering a judgment based on the agreement of the parties for this specific purpose. In Croatian criminal procedure, if the criminal proceedings against co-defendants are separated, in the second proceedings a person who still has the role of defendant in the first criminal proceedings may not be heard as a witness (Art. 284 point $3 \mathrm{CPA}$ ). Thus, the defendant in the first proceedings now in the second proceedings, in the role of witness, would have to testify truthfully and thus he/ she could incriminate him/herself as a defendant in the first trial..$^{53}$ But once the defendant becomes a convicted person, he/she may be questioned as a witness

prakse Pravni fakultet Sveučilišta u Zagrebu, Zagreb, 2019, p. 231

49 Ibid. See also Ivičević Karas, op. cit. note 8, p. 12

50 Pajčić points out that a witness, mainly treated as an object of criminal procedure, is in a much more unfavourable position than the defendant who is "(fortunately) much more a subject of the proceedings than he is an object”. Pajčić, M., Ugroženi svjedoci u kaznenom postupku, Hrvatski ljetopis za kazneno pravo i praksu, vol. 12 , no. 1, 2005, p. 33

51 Ivičević Karas, op. cit. note 48, p. 231

52 Crown witnesses first appeared in England and later spread to the United States. Damaška, M., Dokazno pravo u kaznenom postupku: orisi novih tendencija, Pravni fakultet u Zagrebu, Zagreb, 2001, p. 77

53 See Pajčić, $o p$. cit. note 50, p. 34 
in another criminal procedure, ${ }^{54}$ with regard to the same criminal offence and his/her former co-defendants. The rules on a unified criminal procedure against all co-perpetrators, which prevent the mixing of procedural roles, no longer apply after one of them is convicted. On one hand, it is possible to question the credibility of the testimony which was motivated by reaching a settlement, since "repentant witnesses have an interest in obtaining relief from justice by falsely charging another person" ${ }^{55}$ On the other hand, there is no guarantee that the witness will testify exactly as he/she promised while plea-bargaining in the capacity of defendant. ${ }^{56}$ Finally, there is no rule that would relativise the probative value of a testimony which is the result of plea-bargaining. Such relativisation is prescribed for the testimony of a witness granted witness immunity, or for the testimony of an endangered witness (and the crown witness will generally be an endangered witness), in such a way that a conviction cannot be based solely on the testimony of that witness (Article $298 \mathrm{CPA}$ ). ${ }^{57}$ Therefore, there is obvious inconsistency in the regulation of these consensual instruments that may serve the same specific and delicate purpose: obtaining testimony for the needs of another criminal procedure. A simpler procedure involving fewer formalities, and the "full credibility" of the obtained evidence (testimony), may lead to the "excessive use" of judgment based on the agreement of the parties for the purpose for which the crown witness was actually especially designed.

\subsection{Proportionality between the gravity of criminal offences and statements obtained through consensual forms}

This brief overview of consensual forms in Croatian criminal procedure has shown the distinction between forms that are envisaged for less serious criminal offences, and those envisaged for more serious ones. The discussion on the objectives of consensual justice has shown that all existing instruments contribute to the efficiency and economy of proceedings. The penal order and the conditional deferral or withdrawal of criminal prosecution apply to the same group of criminal offences, punishable by imprisonment of up to five years, in compliance with trends in international law. In addition, the consensual approach may be relatively easily justified by the nature and gravity of the less serious criminal offences involved and consequently by the less accentuated public interest to prosecute. Yet, the huge disproportion in the application of these two instruments could indicate the

\footnotetext{
54 Krapac, op. cit. note 16, p. 433. See also Đurđević, Z., Procesna jamstva obrane prema suokrivljeniku kao svjedoku optužbe, Hrvatski ljetopis za kazneno pravo i praksu, vol. 16, no. 2, 2009, p. 792

55 Damaška, op. cit. note 52, p. 78. See also Đurđević, op. cit. note 54, p. 795

56 Ivičević Karas, op. cit. note 48, pp. 240-241

57 Ibid., pp. 241-242
} 
need for the legislator to reconsider whether the scope of application of these two instruments really should coincide.

With regard to the specific purpose of bargaining, obtaining testimony revealing other criminal offences and perpetrators, the situation is more complicated. Forms that serve exclusively this purpose, the crown witness and witness immunity, are applicable in cases of the most serious criminal offences, and provided that the defendant has not committed any of the more serious criminal offences. The legislator prescribed the requirement of the strict proportionality of the importance of the statement (testimony) obtained through a particular consensual form on one hand, and the gravity of the criminal offence committed by the suspect/defendant or witness on the other hand, meaning that "the public interest in obtaining that person's testimony is stronger than the public interest in his/her criminal prosecution". ${ }^{58}$ This is why the status of crown witness or witness immunity cannot be granted to persons who have committed particularly serious criminal offences. Proportionality is also guaranteed by limiting the application of these consensual forms to the most serious criminal offences that justify the application of the principle of discretionary prosecution. This follows comparative trends. ${ }^{59}$

Here again, judgment based on the agreement of the parties does not fit into the described legal framework, since it can be applied to all criminal offences. This is not in line with comparative law solutions ${ }^{60}$ In French law, for instance, even if the scope of application of the French version of plea bargaining - la comparution sur reconnaissance préalable de culpabilité - is gradually expanding, it is still not expected to cover the most serious offences from the group of medium serious criminal offences (délits). ${ }^{61}$ The Italian model of plea bargaining - patteggiamento - can be applied to criminal offences punishable by imprisonment of up to seven and a half years, while certain offences, including offences of organised crime and sexual crimes, are explicitly excluded from bargaining. ${ }^{62}$ Finally, the interest of conducting a transparent criminal procedure, including a public trial and other fair trial guarantees, is particularly important with regard to more serious criminal offences, ${ }^{63}$ so much so that the need to increase efficiency and reduce the costs of proceedings can hardly compete with it.

\footnotetext{
$58 \quad$ Krapac, op. cit. note 1, p. 498

59 See Labs, op. cit. note 39, pp. 29-30

60 Ivičević Karas; Puljić, op. cit. note 2, p. 843

61 See Perrocheau, V., La composition pénale et la comparution sur reconnaissance de culpabilité : quelles limites à l'omnipotence du parquet? Droit et Société, vol. 74, 2010, p. 60

62 Vitiello, op. cit. note 10, p. 260

63 Tomičić, Z.; Novokmet, A., Nagodbe stranaka u kaznenom postupku - dostignuća i perspektive, Pravni vjesnik, vol. 28, no. 3-4, 2012, p. 180; and Ivičević Karas; Puljić, op. cit. note 2, p. 844
} 
Unlike judgment based on the agreement of the parties, the crown witness and witness immunity incorporate, as explained above, rather strict proportionality between the public interest of obtaining testimony and the public interest of prosecution. On one hand, this objection could be countered with arguments that a judgment based on the agreement of the parties, unlike the crown witness and witness immunity, actually implies conviction, which then satisfies the public interest for prosecution and condemnation. However, on the other hand, judgment based on the agreement of the parties may be applied to any criminal offence, without any proportionality test, while the bargained punishment may sometimes be considered only "symbolic", as the law allows for the significant mitigation of penalties prescribed by law for particular criminal offences in the case of plea-bargaining, ${ }^{64}$ to such an extent that the punishment of imprisonment may be replaced by a fine or community service. ${ }^{65}$ Pronouncing symbolic punishments for the most serious criminal offences does not contribute to the transparency of criminal justice and public trust in the system. Thus, this normative deficiency could be compensated through stricter judicial control over this consensual form, which will be discussed below.

\subsection{Powers of the court (judicial control)}

The role of the court in different forms of consensual procedures is quite justifiably a matter of lively debate. The concept of consensual justice implies the dominant roles of the two parties, while the role of the court, depending on the particular consensual form, may even be excluded or limited to a certain extent. It can be expected that the court will have a more important role in legal systems based on the inquisitorial principle and the principle of seeking material truth. ${ }^{66}$ Yet, even if the court had rather limited possibilities to establish the relevant facts and "reveal the truth" within any consensual procedure, it should have the power to review whether the defendant waived his/her right to a fair trial voluntarily and whether the confession complies with the evidence gathered in the investigation

64 The Criminal Code (Kazneni zakon, Official Gazette 125/11, 144/12, 56/15, 61/15, 101/17, 118/18, 126/19) (hereinafter CC) prescribes that "the punishment may be reduced by up to half of the minimum punishment obtained by reduction", when the rules on punishment mitigation apply, "but cannot be any shorter that three months imprisonment" (Article 49(2) CC). See Ivičević Karas, op. cit. note 8, p. 10

65 See Turković, K. et al., in: Turković, K.; Maršavelki, A. (eds.), Komentar Kaznenog zakona Narodne novine, Zagreb, 2012, p. 72

${ }_{66}$ For instance, in German criminal procedure, the court actively participates in plea-bargaining. See Tomičić; Novokmet, op. cit. note 63, p. $169-170,185$ 
stage. ${ }^{67}$ In the judgment Deweer v. Belgium, the European Court of Human Rights concluded that consensual forms of proceedings are not in themselves contrary to the right to a fair trial, as the defendant may waive the rights guaranteed in Art. 6 para. 1 ECHR, but a claim of waiver should be subjected to "particularly careful review". ${ }^{68}$ Besides, the judicial review should guarantee "the fairness of the deal", ${ }^{69}$ and mandatory and active judicial scrutiny is particularly important in cases of serious criminal offences. ${ }^{70}$ Finally, the judge is actually the "main guardian" of the credibility of consensual justice, and should therefore have the authority to accept or refuse the reached agreement. ${ }^{11}$

In Croatian law, the principle of judicial control over the application of the principle of the legality of criminal prosecution during pre-trial proceedings has been raised at the constitutional level. ${ }^{72}$ It implies that there is an efficient mechanism of judicial protection against unlawful, i.e. arbitrary, criminal prosecution, ${ }^{73}$ and it is particularly important in consensual forms. ${ }^{74}$ Therefore, the court has an active role in consensual forms that are based on the principle of mandatory prosecution (legality) - judgment based on agreement of the parties and a penal order, but also in a consensual procedure that results in granting a suspect or defendant the status of crown witness, which is based on the principle of discretionary prosecution, as described above. On the other hand, conditional deferral or withdrawal of criminal prosecution and granting a witness immunity, which are also based on the principle of discretionary prosecution, do not involve any judicial control.

With reference to consensual forms based on the principle of mandatory prosecution, judgment based on the agreement of the parties and penal orders, it should be stressed once again that both instruments imply a judgment of conviction and imposing a punishment. In the procedure of issuing a penal order, the role of the

67 Frommann, M., Regulating Plea-Bargaining in Germany: Can the Italian Approach Serve as a Model to Guarantee the Independence of German Judges, Hanse Law Review, vol. 5, no. 1, 2009, p. 220

68 ECHR, Deweer v. Belgium, 6903/75, 27 February 1980, para 49. Harris, D. J.; O’Boyle, M.; Bates, E. P.; Buckley, C. M., Harris, O'Boyle and Warbrick Law of the European Convention on Human Rights, Oxford University Press, 2018, p. 410

69 Jimeno-Bulnes, op. cit. note 7, pp. 451, 453

70 Garoupa, op. cit. note 11, p. 355

71 Jung, op. cit. note 3, p. 121

72 See Novokmet, A.; Jukić, M., Sudska kontrola prethodnog postupka - istraživanje prakse županijskih sudova u Osijeku, Splitu, Rijeci, Varaždinu i Zagrebu, Hrvatski ljetopis za kazneno pravo i praksu, vol. 22, no. 2, 2015, p. 454

73 Ibid.

74 See Đurđević, Z., Osvrt na rezultate rada radne skupine Ministarstva pravosuda za uskladivanje Zakona o kaznenom postupkus Ustavom Republike Hrvatske, Hrvatski ljetopis za kazneno pravo i praksu, vol. 20, no. 1,2013 , note 49 , p. 23 
court includes control of formal requirements, as well as whether the request for issuing a penal order is substantiated by sufficient grounds, i.e. sufficient data contained in the indictment, and also the appropriateness of the proposed punishment or other measure (Article $543 \mathrm{CPA}$ ). Though judicial control is provided, Bonačić pointed to some important deficiencies, such as the lack of control over whether the state attorney has complied with the deadlines prescribed for filing an indictment (once the preliminary investigation has come to an end), as well as the lack of control over whether the indictment contains all the prescribed parts. ${ }^{75}$

As concerns judgment based on the agreement of the parties, as previously stated, the court may refuse the statement (on the agreement of the parties) only if it is not in accordance with the sentencing prescribed by law, or if the agreement is not otherwise lawful (Article 361(3) CPA). Control of the "sentencing prescribed by law" should imply control not only of whether the punishment was imposed within the prescribed penalty, but also whether it was just and fair, and whether the agreed punishment has been assessed in accordance with the purpose of punishment, ${ }^{76,77}$ i.e. whether all mitigating and aggravating circumstances prescribed by the Criminal Code have been taken into account. ${ }^{78}$ There are good arguments in favour of such a position, including the one which relies on the Criminal Code which explicitly prescribes the possibility (and not the obligation) for the court to pronounce a milder punishment than the one prescribed for a particular criminal offence when the state attorney and the defendant have reached an agreement (Article 48(3) CC). ${ }^{79}$ Yet, the Supreme Court took the opposite approach and explicitly rejected such interpretation, and specified that the court may only question whether the punishment fits the legislative framework, but not its adequacy from the point of view of the circumstances that are relevant for the choice of the type and the measure of the punishment. ${ }^{80}$ In circumstances where the legislative framework allows, in plea-bargaining, a significant mitigation of the punishment

75 Bonačić, op. cit. note 46, p. 205-206

76 Đurdević, op. cit. note 74, p. 93

77 The judgment at the request of the parties in the investigation, which preceded a judgment based on agreement, actually implied the power of the court to assess whether the proposed sanction was appropriate in the concrete case. Krstulović, A., Nagodbe stranaka u suvremenom kaznenom postupku, Hrvatsko udruženje za kaznene znanosti i praksu, MUP RH, Zagreb, 2007, p. 175

78 Turudić; Pavelin Borzić; Bujas, op. cit. note 38, p. 145

79 "The court may also impose a milder sentence than the one prescribed for a certain criminal offence when the state attorney and the defendant have agreed on that" (Article 48(3) CC). This is an optional circumstance for mitigating the sentence, since the court should have the possibility to intervene "as a guarantor of a fair trial, especially in cases of an insufficiently protected and weak defendant". Turković et al., op. cit. note 65, p. 72

80 VSRH, Kzz 38/16-3, 21 September 2017, also Kzz 17/2018-8, 8 and 9 May 2018. Ivičević Karas, op. cit. note 8 , p. 10 
prescribed for a certain offence, including the most serious criminal offences such as corruption and organised crime, but also murder, ${ }^{81}$ the attitude of the Supreme Court may be strongly criticised. As Garoupa and Stephen pointed out, judicial scrutiny of plea-bargaining serves to "mitigate the misalignment of goals between the prosecutor and the rest of the community" ${ }^{82}$ Considering this issue, the Italian Constitutional Court declared the provisions of the new Italian Code of Criminal Procedure regulating patteggiamento unconstitutional, because the court was deprived of the possibility to assess the appropriateness of the sentence. ${ }^{83,84}$ The problem was that the court was not explicitly attributed the power to control the compatibility of the agreed sentence and the seriousness of the offence, and therefore was deprived of the power to enforce the constitutional provision proclaiming that rehabilitation is the purpose of punishment. ${ }^{85}$

With regard to the conditional deferral or withdrawal of criminal prosecution and witness immunity, consensual forms that do not involve any kind of judicial control of the legality of their application, it is also possible to indicate important objections. As previously explained, the conditional deferral or withdrawal of criminal prosecution implies imposing informal sanctions, which in their content match the formal punishments and other measures prescribed in the Criminal Code, without any judicial control over the legality of prosecution and whether imposing such sanctions is substantiated by evidence contained in the case file. Even though it is true that the suspect or defendant will benefit from avoiding criminal sentencing and from not having the crime entered into his/her criminal record, and all the consequences this entails, the informal sanction imposed in a specific case may be even more grave than the formal one which could, for instance, be imposed with a penal order. However, the procedure is informal and the level of guaranteed rights is much lower than in formal criminal proceedings, which calls into question respect for the constitutional principle of the equality of all before the law. ${ }^{86}$

${ }_{81}$ About a judgment based on the agreement of the parties rendered in the case of a murder, see Cambj, N., Sporazumijevanje prema Noveli Zakona o kaznenom postupku, Hrvatski ljetopis za kazneno pravo i praksu, vol. 20, no. 2, 2013, p. 667. See also Ivičević Karas; Puljić, op. cit. note 2, p. 843

82 Garoupa; Stephen, op. cit. note 11, p. 355

83 La Corte Costituzionale, Sentenza N.313, 2 July 1990, available at: [http://www.giurcost.org/decisioni/1990/0313s-90.html], accessed 08. May 2020

84 Frommann, op. cit. note 67, p. 216

85 See Li, C., Adversary System Experiment in Continental Europe: Several Lessons from the Italian Experience, Journal of Politics and Law, vol. 1, no. 4, 2008, p. 17

86 Puharić; Radić, op. cit. note 22, p. 638 
Finally, granting the status of witness immunity, without any judicial control over legality and proportionality, may disturb the transparency of criminal justice, especially in cases where a person has the role of witness, even though it is quite clear from the content of his/her testimony given at the (public) trial that that person should have actually been prosecuted and tried together with his/her alleged co-perpetrators. This again points to the problem of mixing procedural roles (supra 3.1).

In conclusion, the issue of effective judicial control of various consensual forms is key to ensuring the transparency of court proceedings and criminal justice in general. Only the court has the capacity to independently control the legality of all the aspects of the particular agreement. Yet, the precondition for this is that the legal regulation of each consensual procedure is complete, clear and harmonised in all relevant elements with other consensual forms.

\subsection{Victims' rights}

The role of the victim in criminal procedure had traditionally been neglected, mostly due to the understanding that the state attorney represents not only the public interest, but also the victims' interests in criminal proceedings. This certainly applies with regard to those consensual forms that are based on the principle of mandatory prosecution which is binding on the state attorney and which implies prosecution until the proceedings are closed with a final judgment. Yet, if we look at consensual forms in Croatian criminal procedure, we notice that the victim has a specific role in only two of them: conditional deferral or withdrawal of criminal prosecution and judgment based on the agreement of the parties. Requiring the victim's consent may be justified by pragmatic reasons, such as in the case of conditional deferral or withdrawal of criminal prosecution, knowing that in Croatian criminal procedure a victim has the right to take over the prosecution from the state attorney who desists from it. Still, there was no obstacle for the legislator to exclude that possibility for the victim. Therefore, it is possible to conclude that the legislator sought to include the victim into negotiations for specific reasons, related to the ideas of restorative justice that otherwise influenced the development of this consensual instrument. ${ }^{87}$ Involving the victim may significantly improve his/ her position, not only through consulting the victim on whether to prosecute, but also by adapting the content of informal sanctions to the interests of the victim. ${ }^{88}$

\footnotetext{
$87 \quad$ See Carić, op. cit. note 27, p. 605-606

88 See Sirotić, op. cit. note 18, p. 164
} 
On the other hand, involving victims in the plea-bargaining procedure for serious criminal offences of a specific nature - against life and limb and sexual liberty was probably motivated by the need to include the victim into the procedure, leading to a potentially significantly reduced sentence. The victim's participation was not originally envisaged, but it was prescribed in a legislative amendment of 2013. The inclusion of the victim into bargaining, as might have been expected, was not unanimously accepted. Some of the remarks pointed out that victims, or members of their families, would very rarely give their consent to the agreement, ${ }^{89}$ and thereby would hinder the application of this consensual instrument in practice.

Finally, the role of the victim could perhaps be seen as compensation for not providing any kind of proportionality test in the application of this consensual form, especially in cases of serious criminal offences. Yet on the other hand, the most serious criminal offences, or certain types of criminal offences, should perhaps have been excluded from bargaining in the first place, which would provide at least a certain amount of proportionality. Having in mind that other consensual forms do not involve the victims' participation, the legislator's inconsistent approach to the issue is quite evident. In the light of the new position of the victim in criminal proceedings, and all the (procedural and extra-procedural) rights granted to the victim primarily by the Victims' Rights Directive, ${ }^{90}$ the position of a victim in consensual justice should be reconsidered and the legislator should take a coherent approach to the issue.

\subsection{Procedural and defence rights}

\subsubsection{The right to plea-bargain?}

The problem of the defendant's procedural and defence rights, and the more general problem of the defendant's position in consensual justice, is the topic of many studies conducted so far. The temptation of assuring more lenient punishment on one hand, and the need to waive the fundamental guarantees of a fair trial, including the presumption of innocence in return, put the defendant in a very unfavourable position. These issues will not be discussed again here. Instead, the focus is on a specific peculiarity of Croatian criminal procedure - the right to plea-bargain. The CPA stipulates that the defendant has the right to agree on punishment and

89 Cambj, op. cit. note 81, p. 676

90 Directive 2012/29/EU of the European Parliament and of the Council of 25 October 2012 establishing minimum standards on the rights, support and protection of victims of crime, and replacing Council Framework Decision 2001/220/JHA. Official Journal of the European Union, L 315, 14 November 2012 
other measures prescribed in Article 360(4) CPA. In other words, the defendant has the right to negotiate and reach an agreement with the state attorney, which may result in a judgment based on an agreement of the parties. In the original text of the CPA of 2008, the defendant had an even broader right to "plead guilty and agree on a sanction". The reasoning given with the legislative proposal referred to the International Covenant on Civil and Political Rights, the ECHR and the Constitution of the Republic of Croatia, without reference to any concrete provisions, ${ }^{91}$ so it remains unclear what inspired the legislator.

Yet, this proclamation does not comply with the regulation of this consensual form. The defendant may propose an agreement to the state attorney, but the state attorney has very broad discretion to decide whether to negotiate or not. The exercise of any right of the defendant may not entirely depend on the discretion of the state attorney. In addition, there is no effective legal remedy guaranteeing the defendant respect and protection of the proclaimed right. So, clearly, the defendant has no right to plea-bargain and the state attorney has no duty to negotiate. ${ }^{92}$ Therefore, it remains to conclude that the Croatian legislator proclaimed this specific right of the defendant, without providing a mechanism for exercising this right, nor an effective remedy for its protection.

\subsubsection{Safeguards in the case of withdrawal from the agreement}

From the perspective of procedural and defence rights, it should be pointed out that if the parties withdraw from the agreement, the defendant's statement (which may include a confession) and all the documentation on the agreement must be excluded from the case file. This rule applies to consensual forms involving bargaining - the judgment based on the agreement of the parties (Article 362(2) CPA) and witness immunity (Article 286(6) CPA), but it is not explicitly prescribed for the crown witness. In this manner, the suspect or defendant should be adequately protected from any negative consequences of his/her willingness to negotiate and reach agreement.

\subsubsection{Mandatory defence?}

During the entire procedure of plea-bargaining, drafting a statement on the agreement and presenting it to the court, the defendant must be assisted by a defence counsel. Mandatory defence is a precondition for the lawfulness of the statement.

\footnotetext{
91 Nacrt konačnog prijedloga Zakona o kaznenom postupku, op. cit. note 32, p. 173

92 This applies to the original model of plea-bargaining developed in the United States. See Mrčela, op. cit. note 31, p. 356-357
} 
The same rule applies when the witness agrees with the state attorney on granting witness immunity - the witness must be assisted by a lawyer (Article 286(3) CPA). Yet, the same does not apply in the procedure of granting the status of crown witness, but it does when the State Attorney General negotiates on the abolishment or reduction of a sentence, or the release on parole of a convicted member of a criminal organisation/association, in exchange for a testimony (Article 37 of the Act on USKOK, supra 2.3). A possible reason for excepting the crown witness from explicit mandatory defence may be the presumption that the defendant will have counsel on some other basis for mandatory defence. But even then, a consistent approach by the legislator would require the prescribing of mandatory defence also for the procedure of granting the status of crown witness.

On the other hand, the conditional deferral or withdrawal of criminal prosecution, as well as the penal order, does not require the mandatory presence of a defence counsel, even though the first instrument implies imposing informal sanctions, and the latter means that the defendant will be convicted without the court holding a trial. Of course, lodging a complaint entails the risk of a harsher punishment pronounced at the trial, as well as not agreeing to the proposed informal sanction, and therefore the assistance of a defence counsel in those procedures would be valuable, not just to safeguard efficient defence rights, but also to safeguard the fairness of the proceedings, which is also of important public interest. It is true that both instruments apply to less serious criminal offences, but the complexity of the situation speaks in favour of providing an efficient defence, perhaps not necessarily in the form of mandatory defence, but then certainly through the mechanism of free legal aid which, at present, is not granted to all poor suspects in the earliest phases of proceedings for criminal offences punishable by a fine or imprisonment of up to five years.

\section{CONCLUSION}

This analysis has shown that there are a number of issues that demonstrate the legislator's inconsistent approach to consensual justice in Croatian criminal procedure and in the legal system as a whole. The field of application of different consensual forms has gradually expanded. But while certain instruments have been increasingly applied in practice (the penal order, judgment based on the agreement of the parties), others are hardly applied, although they may be a better designed and more appropriate instrument to achieve a specific purpose such as humanising criminal proceedings in specific cases (conditional deferral or withdrawal of criminal prosecution in comparison with the penal order) or obtaining witness testimony to reveal and prove other criminal offences and perpetrators in another 
criminal procedure (the crown witness in comparison with judgment based on the agreement of the parties). The reason for this may lie in the pragmatic approach taken by practitioners, especially state attorneys who have huge discretionary powers in any agreement, meaning that they may in a particular case simply opt for the least complicated consensual form to reach a specific purpose.

Furthermore, at the normative level, there are many inconsistencies regarding the type and gravity of "negotiable" criminal offences, the purposes of particular consensual forms, judicial control, the role of the victim, and the effectiveness of procedural and defence rights. Taking a systematic approach to consensual justice in Croatian criminal procedure would involve a detailed analysis of each form of consensual procedure in respect of each of the stated elements, keeping in mind all other existing consensual procedures. Particular attention should be paid to harmonising all consensual forms in order for them to be coherent and for them to contribute to the transparency of criminal procedure and the criminal justice system as a whole.

\section{REFERENCES}

\section{BOOKS AND ARTICLES}

1. Alkon, C., Plea Bargaining as a Legal Transplant: A Good Idea for Troubled Criminal Justice Systems, Transnational Law \& Contemporary Problems, vol. 19, 2010, pp. 355-418

2. Bonačić, M., Kritički osvrt na hrvatsko zakonodavno uređenje instituta kaznenog naloga, $\mathrm{Hr}$ vatski ljetopis za kazneno pravo i praksu, vol. 22, no. 1, 2015, pp. 185-216

3. Cambj, N., Sporazumijevanje prema Noveli Zakona o kaznenom postupku, Hrvatski ljetopis za kazneno pravo i praksu, vol 20., no. 2, 2013, pp. 663-678

4. Carić, M., Načelo svrhovitosti (oportuniteta) kaznenog progona iz članka 175. Zakona o kaznenom postupku i njegova primjena u praksi, Hrvatski ljetopis za kazneno pravo i praksu, vol. 8, no. 1, 2001, pp. 603-646

5. Damaška, M., Dokazno pravo u kaznenom postupku: orisi novih tendencija, Pravni fakultet u Zagrebu, Zagreb, 2001

6. Damaška, M., Napomene o sporazumima u kaznenom postupku, Hrvatski ljetopis za kazneno pravo i praksu, vol. 11, no. 1, 2004, pp. 3-20

7. Đurđević, Z., Osvrt na rezultate rada radne skupine Ministarstva pravosuda za uskladivanje Zakona o kaznenom postupku s Ustavom Republike Hrvatske, Hrvatski ljetopis za kazneno pravo i praksu, vol. 20, no. 1, 2013, note 49, pp. 3-100

8. Đurđević, Z., Procesna jamstva obrane prema suokrivljeniku kao svjedoku optužbe, Hrvatski ljetopis za kazneno pravo i praksu, vol. 16, no. 2, 2009, pp. 783-808

9. Frommann, M., Regulating Plea-Bargaining in Germany: Can the Italian Approach Serve as a Model to Guarantee the Independence of German Judges, Hanse Law Review, vol. 5, no. 1, 2009, pp. 197-220 
10. Garoupa, N.; Stephen, F. H., Why Plea-Bargaining Fails to Achieve Results in So Many Criminal Justice Systems: A New Framework for Assessment, Maastricht J. Eur. \& Comp. L., vol. 15, no. 3, 2008, pp. 323-358

11. Glasnović Gjoni, V.; Sirotić, V., Uvjetni odustanak od kaznenog progona i praksa Općinskog suda u Puli-Pola, Pravni vjesnik, vol. 32, no. 3-4, 2016, pp. 157-181

12. Harris, D. J.; O’Boyle, M.; Bates, E. P.; Buckley, C. M., Harris, O'Boyle and Warbrick Law of the European Convention on Human Rights, Oxford University Press, 2018

13. Ivičević Karas, E., Prilog raspravi o problemu miješanja procesnih uloga u kaznenom postupku, in: Turković, K.; Munivrana Vajda, M.; Dragičević Prtenjača, M. (eds.), Kazneno pravo: sinergija teorije i prakse, Pravni fakultet Sveučilišta u Zagrebu, Zagreb, 2019, pp. 229-243

14. Ivičević Karas, E.; Puljić, D., Presuda na temelju sporazuma stranaka u hrvatskom kaznenom procesnom pravu i praksi Županijskog suda u Zagrebu, Hrvatski ljetopis za kazneno pravo i praksu, vol. 20, no. 2, 2013, pp. 823-849

15. Jimeno-Bulnes, M., American Criminal Procedure in a European Context, Cardozo Journal of International \& Comparative Law, vol. 21, 2013, pp. 409-459

16. Jung, H., Plea Bargaining and its Repercussions on the Theory of Criminal Procedure, European Journal of Crime, Criminal Law and Criminal Justice, Vol. 5, no. 2, 1997, pp. 112-122

17. Krapac, D., Kazneno procesno pravo, Prva knjiga: Institucije, Narodne novine, Zagreb, 2015

18. Krapac, D., Presuda na zahtjev stranaka u stadiju istrage u hrvatskom kaznenom postupku, in: Pavišić, B. (ed.), Decennium Moztanicense Rijeka, 2008, pp. 137-150

19. Krapac, D., Zakon o kaznenom postupku i drugi izvori hrvatskog kaznenog postupovnog prava, Narodne novine, Zagreb, 2008

20. Krstulović, A., Nagodbe stranaka u suvremenom kaznenom postupku, Hrvatsko udruženje za kaznene znanosti i praksu, MUP RH, Zagreb, 2007

21. Labs, K., Die Strafrechtliche Kronzeugenregelung - Legitimation einer rechtlichen Grauzone?, Tectum Verlag, Marburg, 2016

22. Li, C., Adversary System Experiment in Continental Europe: Several Lessons from the Italian Experience, Journal of Politics and Law, vol. 1, no. 4, 2008, pp. 13-21

23. Mrčela, M., Presuda na zahtjev stranaka u istrazi, Hrvatski ljetopis za kazneno pravo i praksu, vol. 9, no. 2, 2002, pp. 349-371

24. Novokmet, A.; Jukić, M., Sudska kontrola prethodnog postupka - istraživanje prakse županijskih sudova u Osijeku, Splitu, Rijeci, Varaždinu i Zagrebu, Hrvatski ljetopis za kazneno pravo i praksu, vol. 22, no. 2, 2015, pp. 453-482

25. Pajčić, M., Ugroženi svjedoci u kaznenom postupku, Hrvatski ljetopis za kazneno pravo i praksu, vol. 12, no. 1, 2005, p. 33-62

26. Pavišić, B., Novi hrvatski Zakon o kaznenom postupku, Hrvatski ljetopis za kazneno pravo i praksu, vol. 15, no. 2, 2008, pp. 489-602

27. Perrocheau, V., La composition pénale et la comparution sur reconnaissance de culpabilité : quelles limites à l'omnipotence du parquet?, Droit et Société, vol. 74, 2010, pp. 55-71

28. Puharić, B.; Radić, I., Primjena načela svrhovitosti u postupanju prema maloljetnicima, Hrvatski ljetopis za kazneno pravo i praksu, vol. 22, no. 2, 2015, p. 635-670 
29. Sirotić, V., Uvjetna odgoda kaznenog progona punoljetnog počinitelja kaznenog djela, Hrvatski ljetopis za kazneno pravo i praksu, vol. 19, no. 1, 2012, pp. 161-207

30. Tomičić, Z.; Novokmet, A., Nagodbe stranaka u kaznenom postupku-dostignuća i perspektive, Pravni vjesnik, vol. 28, no. 3-4, 2012, pp. 149-190

31. Turković, K. et al., in: Turković, K.; Maršavelki, A. (eds.), Komentar Kaznenog zakona, Narodne novine, Zagreb, 2012

32. Turudić, I.; Pavelin Borzić, T.; Bujas, I., Sporazum stranaka u kaznenom postupku - trgovina pravdom ili?, Pravni vjesnik, vol. 32, no. 1, 2016, pp. 121-153

33. Vitiello, M., Bargained-for-Justice: Lessons from the Italians, The University of the Pacific Law Review, vol. 48, 2017, pp. 247-263

\section{LIST OF NATIONAL REGULATIONS}

1. Kazneni zakon, Official Gazette 125/11, 144/12, 56/15, 61/15, 101/17, 118/18, 126/19

2. Zakon o izmjenama i dopunama Zakona o kaznenom postupku, Official Gazette 58/02

3. Zakon o kaznenom postupku, Official Gazette 110/97, 27/98, 58/99, 112/99, 58/02, $143 / 02,115 / 06$

4. Zakon o kaznenom postupku, Official Gazette 152/08, 76/09, 80/11, 121/11, 91/12, $143 / 12,56 / 13,145 / 13,152 / 14,70 / 17,126 / 19,126 / 19$

5. Zakon o Uredu za suzbijanje korupcije i organiziranog kriminaliteta, Offical Gazette 76/09, $116 / 10,145 / 10,57 / 11,136 / 12,148 / 13,70 / 17$

6. Zakon o Uredu za suzbijanje korupcije i organiziranog kriminaliteta, Offical Gazette 88/01, $12 / 02,33 / 05,48 / 05,76 / 07$

\section{WEBSITE REFERENCES}

1. Ivičević Karas, E., Trial Waiver Systems in Croatia, Towards a Rights-based Approach to Trial Waiver Systems, LEAP, 2019, accessible at: [https:/www.fairtrials.org/sites/default/files/publication_pdf/20190513_Trial_Waivers_Croatia_Final.pdf], accessed 20. April 2020

2. Izvješće Državnog odvjetništva Republike Hrvatske za 2015. godinu, A-447/15, Državno odvjetništvo Republike Hrvatske, Zagreb, travanj 2016., available at: [http://www.dorh.hr/ IzvjesceDrzavnogOdvjetnistvaRepublikeHrvatske], accessed 29. April 2020

3. Izvješće Državnog odvjetnišstva Republike Hrvatske za 2016. godinu, A-561/16, Državno odvjetništvo Republike Hrvatske, Zagreb, travanj 2017., available at: [http://www.dorh.hr/ IzvjesceDrzavnogOdvjetnistvaRepublikeHrvatskeZa], accessed 29. April 2020

4. Izvješće Državnog odvjetništva Republike Hrvatske za 2017. godinu, A-643/17, Državno odvjetništvo Republike Hrvatske, Zagreb, travanj 2018., p. 37, available at: [http://www. dorh.hr/dorh07062018], accessed 29. April 2020

5. Izvješće Državnog odvjetništva Republike Hrvatske o radu državnih odvjetništava u 2019. godini, Državno odvjetništvo Republike Hrvatske, Zagreb, travanj 2020., p. 43, available at: [http://www.dorh.hr/dorh05052020], accessed 03. May 2020

6. Nacrt konačnog prijedloga Zakona o kaznenom postupku, p. 188, accessible at: [https:// vlada.gov.hr/UserDocsImages//2016/Sjednice/Arhiva//57_13.pdf], accessed 24. April 2020 
7. Naputak o pregovaranju i sporazumijevanju s okrivljenikom o priznanju krivnje i sankciji, O-2/09, od 17. veljače 2010., accessible at: [http://www.dorh.hr/PresudaPoSporazumu], accessed 27. April 2020

8. Statistički ljetopis 2018, available at: [https://www.dzs.hr/Hrv_Eng/ljetopis/2018/sljh2018. pdf], accessed 07. May 2020 